\title{
Moringa oleifera Leaf Extract Enhanced Growth, Yield, and Silybin Content While Mitigating Salt-Induced Adverse Effects on the Growth of Silybum marianum
}

\author{
Yun-Kiam Yap ${ }^{1, * \mathbb{D}}$, Fadia El-Sherif ${ }^{1,2}$, Eman S. Habib ${ }^{3}$ and Salah Khattab ${ }^{1,2}$ \\ 1 Department of Biological Sciences, College of Science, King Faisal University, AlAhsa 31982, Saudi Arabia; \\ Felsherif@kfu.edu.sa (F.E.-S.); skhattab@kfu.edu.sa (S.K.) \\ 2 Department of Horticulture, Faculty of Agriculture, Suez Canal University, Ismailia 41522, Egypt \\ 3 Department of Pharmacognosy, Faculty of Pharmacy, Suez Canal University, Ismailia 41522, Egypt; \\ emansnd@yahoo.com \\ * Correspondence: yyap@kfu.edu.sa
}

Citation: Yap, Y.-K.; El-Sherif, F.; Habib, E.S.; Khattab, S. Moringa oleifera Leaf Extract Enhanced Growth, Yield, and Silybin Content While Mitigating Salt-Induced

Adverse Effects on the Growth of Silybum marianum. Agronomy 2021, 11, 2500. https://doi.org/10.3390/ agronomy 11122500

Academic Editors: Rossella Albrizio, Anna Maria Stellacci, Vito Cantore and Mladen Todorovic

Received: 23 October 2021

Accepted: 6 December 2021

Published: 9 December 2021

Publisher's Note: MDPI stays neutral with regard to jurisdictional claims in published maps and institutional affiliations.

Copyright: (c) 2021 by the authors. Licensee MDPI, Basel, Switzerland. This article is an open access article distributed under the terms and conditions of the Creative Commons Attribution (CC BY) license (https:// creativecommons.org/licenses/by/ $4.0 /)$.

\begin{abstract}
Silybin A and B are two major hepatoprotective flavonolignans produced predominantly in Silybum marianum fruits. Similar to other plant secondary metabolites, silybin production is enhanced by biotic or abiotic stresses under the expanse of plant growth and yield. In this study, a novel strategy for enhancing silybin production was investigated by applying a natural plant growth enhancer, moringa leaf extract (MLE), to the S. marianum plants cultivated under salinity abiotic stress. The experiment was conducted using a split-plot design with salinity as the main factor and MLE concentrations as the sub-factor. The individual and combined effects of salinity and MLE on the growth, yield, and silybin content of $S$. marianum were recorded. The MLE at concentrations of $5 \mathrm{~g} / \mathrm{L}$ or $10 \mathrm{~g} / \mathrm{L}$ was applied as foliar spray to $S$. marianum plants, which were irrigated with either tap water or saline (2000 ppm or $4000 \mathrm{ppm}$ ). Our results revealed that $10 \mathrm{~g} / \mathrm{L}$ MLE effectively enhances the growth, yield, and silybin $(\mathrm{A}+\mathrm{B})$ content in $S$. marianum plants not exposed to salinity stress. On the other hand, for plants that were exposed to $4000 \mathrm{ppm}$ salinity, the application of MLE was able to alleviate the salinity-induced adverse effects on some of the plant growth parameters but did not significantly increase their silybin $(A+B)$ compositions. The current study also indicated that the increase in silybin contents was accompanied by the upregulation of the chalcone synthase 1 and 3 genes, which have been implicated in the synthesis of silybin.
\end{abstract}

Keywords: silymarin; high-performance liquid chromatography; bio-stimulant; salinity

\section{Introduction}

Secondary metabolites from many plant fruits and/or seeds are often good sources of bioactive compounds used in medicinal and pharmaceutical industries [1]. Silymarin is one of these bioactive compounds and has been used in treating various forms of liver disorders [2]. Silymarin is produced by the fruits of Silybum marianum (L.) Gaertn (milk thistle, Asteraceae), an annual or biannual medicinal plant indigenous to the Middle East and Mediterranean regions. Silymarin is a stereoisomeric flavonolignan mixture of silybin (SB), isosilybin (ISB), silydianin (SD), silychristin (SC), and their precursor taxifolin (TXF) [3] The hepatoprotective effects of silymarin have been attributed to natural silybin, a mixture of silybin A and silybin B [4,5]. Naturally, secondary metabolites are synthesized in plants as responses to various biotic or abiotic stresses such as drought or salinity. Elicitation is the process in which abiotic or biotic stress factors are applied to plants, especially medicinal plants, to enhance their bioactive compound production. The elicitation of silymarin production in S. marianum by various elicitors has been documented [6-9]. Nevertheless, one of the problems often faced in elicitation studies is the adverse effects of elicitors on plant growth or yield. 
Fertilizers are substance that are applied to plants to enhance their growth and yield. Lately, the replacement of synthetic chemical fertilizers with organic fertilizers has been highly promoted as a sustainable agricultural strategy because organic fertilizers promote plant growth without risks of chemically polluting the land or water sources. Among the various organic fertilizers, plant extracts have been documented to enhance plant growth by improving nutrient usage efficiency and by alleviating various biotic or abiotic stress effects on plants [10]. Moringa oleifera, from the family Moringaceae, is well known for its nutritional and medicinal properties [11]. The moringa leaf extract (MLE) has been classified as one of the prominent bio-stimulants due to its rich minerals, free amino acids, vitamins, phytohormones, and antioxidant contents [12]. Moreover, the preparation of MLE in $80 \%$ ethanol or in water is both cost-efficient and eco-friendly [12]; therefore, it has been used as a natural growth promoter and/or stress-reducing agent for many plant species [12-18].

Chalcone synthase (EC 2.3.1.74) has been implicated in the biosynthesis of multiple secondary metabolites in plants, fungi, and bacteria [19]. In S. marianum, chalcone synthase catalyzes the first committed step of the biosynthesis of taxifolin, the flavonoid precursor that forms the flavonolignans mixture of silymarin. Three $S$. marianum chalcone synthase genes ( $\mathrm{S} m \mathrm{CHS1}$, SmCHS2, and SmCHS3) have been identified and partially cloned. These genes were reported to be differentially expressed in various organs of the plants during the early and late flowering stages [20]. El-Garhy et al. [8] have reported that these CHS genes were differentially activated by salinity and gamma radiation and that their activation profiles were found to be closely associated with silymarin accumulation in fruit samples.

In this study, salinity stress was imposed on S. marianum plants by irrigating the plants with different concentrations of saline. The effect of salinity on $S$. marianum was investigated as it is one of the abiotic stresses that is threatening plant growth and production worldwide, and being a stress factor, it could be manipulated to enhance the production of secondary metabolites, particularly silymarin. In addition, MLE was applied as a foliar spray to S. marianum plants to examine its plant growth and yield enhancement effects as well as its potential in alleviating adverse effects from salinity stress. The aim of this study was to explore the best strategy for enhancing silymarin production with minimal adverse effects on plant growth and yield by investigating the combining effects of salinity and MLE on S. marianum plant growth, yield, and silybin (A + B) production. Furthermore, the expression of the S. marianum chalcone synthase genes (CHS 1, CHS 2, and CHS 3) in the experimental plants was examined to establish a correlation between silybin $(\mathrm{A}+\mathrm{B})$ content and the expression of these genes.

\section{Materials and Methods}

\subsection{Source of Moringa Leaves}

Young leaves of Moringa oleifera were collected from fully grown (four-year-old) trees planted at the AL Sahab farm, Al-Hassa, Saudi Arabia.

\subsection{Chemical Analysis of Moringa Leaves}

Table 1 showed the chemical composition of Moringa oleifera leaves. Analyses of the elements and secondary metabolites were performed on dried leaves, while fresh leaves were used to determine the free amino acid, vitamin, and plant growth regulator contents $[13,14]$. 
Table 1. Chemical composition of Moringa oleifera leaves.

\begin{tabular}{|c|c|c|}
\hline Chemical & Amount & Unit \\
\hline Calcium & 440 & $\mathrm{mg} / 100 \mathrm{~g}$ \\
\hline Copper & 0.07 & $\mathrm{mg} / 100 \mathrm{~g}$ \\
\hline Iron & 0.85 & $\mathrm{mg} / 100 \mathrm{~g}$ \\
\hline Magnesium & 42 & $\mathrm{mg} / 100 \mathrm{~g}$ \\
\hline Phosphorus & 70 & $\mathrm{mg} / 100 \mathrm{~g}$ \\
\hline Potassium & 259 & $\mathrm{mg} / 100 \mathrm{~g}$ \\
\hline Zinc & 0.16 & $\mathrm{mg} / 100 \mathrm{~g}$ \\
\hline Protein & 6.70 & $\mathrm{~g} / 100 \mathrm{~g}$ \\
\hline Fat & 1.70 & $\mathrm{~g} / 100 \mathrm{~g}$ \\
\hline Carbohydrate & 12.5 & $\mathrm{~g} / 100 \mathrm{~g}$ \\
\hline Arginine & 406.6 & $\mathrm{mg} / 100 \mathrm{~g}$ \\
\hline Histidine & 149.8 & $\mathrm{mg} / 100 \mathrm{~g}$ \\
\hline Isoleucine & 299.6 & $\mathrm{mg} / 100 \mathrm{~g}$ \\
\hline Leucine & 492.2 & $\mathrm{mg} / 100 \mathrm{~g}$ \\
\hline Lysine & 342.4 & $\mathrm{mg} / 100 \mathrm{~g}$ \\
\hline Methionine & 117.7 & $\mathrm{mg} / 100 \mathrm{~g}$ \\
\hline Phenylalanine & 310.3 & $\mathrm{mg} / 100 \mathrm{~g}$ \\
\hline Threonine & 117.7 & $\mathrm{mg} / 100 \mathrm{~g}$ \\
\hline Tryptophan & 107 & $\mathrm{mg} / 100 \mathrm{~g}$ \\
\hline Valine & 374.5 & $\mathrm{mg} / 100 \mathrm{~g}$ \\
\hline Vitamin A & 6.78 & $\mathrm{mg} / 100 \mathrm{~g}$ \\
\hline Vitamin B1 & 0.06 & $\mathrm{mg} / 100 \mathrm{~g}$ \\
\hline Vitamin B2 & 0.05 & $\mathrm{mg} / 100 \mathrm{~g}$ \\
\hline Vitamin B3 & 0.8 & $\mathrm{mg} / 100 \mathrm{~g}$ \\
\hline Vitamin C & 220 & $\mathrm{mg} / 100 \mathrm{~g}$ \\
\hline Gibberellin & 5.4 & $\mathrm{mg} / 100 \mathrm{~g}$ \\
\hline Zeatin & 3.0 & $\mathrm{mg} / 100 \mathrm{~g}$ \\
\hline Indole acetic acid (IAA) & 0.52 & $\mathrm{mg} / 100 \mathrm{~g}$ \\
\hline Total polyphenol & 28.05 & $\mathrm{mg} / \mathrm{g}$ \\
\hline Total flavonoid & 80 & $\mathrm{mg} / \mathrm{g}$ \\
\hline Total tocopherol & 5 & $\mu \mathrm{g} / \mathrm{g}$ \\
\hline Total rutin & 0.27810 & $\mathrm{mg} / \mathrm{g}$ \\
\hline Total gallic acid & 0.12786 & $\mathrm{mg} / \mathrm{g}$ \\
\hline
\end{tabular}

\subsection{Preparation of Moringa Leaf Extracts}

The Moringa oleifera leaf extract (MLE) was prepared by mixing $20 \mathrm{~g}$ of Moringa oleifera air-dried leaves with $675 \mathrm{~mL}$ of $80 \%$ ethanol and left at room temperature for $72 \mathrm{~h}$ with occasional manual swirling [21]. The extracts were filtered with Whatman filter paper, and ethanol was removed by drying the filtrate in a fume hood. The dried extract was then resuspended in $20 \%$ ethanol to achieve final concentrations of 5 and $10 \mathrm{~g} / \mathrm{L}$ of MLE.

\subsection{Silybum Plant Material and Growth Conditions}

A field experiment was conducted during two successive seasons, in 2018 and 2019, at the Agriculture and Veterinary Research and Training Centre, King Faisal University. The Silybum marianum seeds were harvested from plants grown at the Institute for Horticultural Science, Agricultural Research Center (ARC), Department of Medicinal and Aromatic Plants, Giza, Egypt. Dry seeds were germinated in a 24-well $(5 \mathrm{~cm} \times 5 \mathrm{~cm} \times 5 \mathrm{~cm})$ germination tray containing a moist mixture of $(1: 1 v: v)$ sand and peat moss on 1 October of each planting years. After one month, the seedlings were transplanted to plastic pots ( $37.5 \mathrm{~cm}$ in diameter and $27.5 \mathrm{~cm}$ in depth) containing approximately $25 \mathrm{~kg}$ of moist mixture of (1:1 v:v) sand and peat moss per pot. The pots were arranged in a split-plot design with two factors: salinity (control, 2000 ppm, and 4000 ppm) as the main factor (whole-plot), and MLE concentration (control, $5 \mathrm{~g} / \mathrm{L}$, and $10 \mathrm{~g} / \mathrm{L}$ ) as a sub-factor (sub-plot). Each sub-plot contained 28 pots. The chemical properties and composition of the tap water used are shown in Table 2. The controls for salinity and MLE consisted of tap water. Sea salt was 
dissolved in fresh tap water to prepare the saline at 2000 and 4000 ppm salinity. The salinity of all solutions was measured using a portable electrical conductivity meter (YSI EcoSense EC300). The MLE treatments were applied by foliar spray every two months throughout the vegetative growth stage of the S. marianum. The seeds and seedlings (up to two months old) were irrigated with tap water. The salinity treatments begun one month after the transplantation of seedlings from the germination trays to the pots. When the salinity treatment began, extra seedlings from each pot were removed to ensure that each pot contained only a single plant. All irrigations were performed daily up to the soil's water-holding capacity.

Table 2. Chemical properties and compositions of the irrigation water.

\begin{tabular}{cccccccccc}
\hline \multirow{2}{*}{$\begin{array}{c}\text { Salinity } \\
\text { Level (ppm) }\end{array}$} & \multicolumn{4}{c}{ Cations (meq/L) } & \multicolumn{5}{c}{ Anions (meq/L) } \\
\cline { 2 - 8 } & $\mathbf{C a}^{2+}$ & $\mathbf{M g}^{2+}$ & $\mathbf{N a}^{+}$ & $\mathbf{K}^{+}$ & $\mathbf{C O}_{3}{ }^{2-}$ & $\mathbf{H C O}_{3}{ }^{-}$ & $\mathbf{S O}_{4}{ }^{2-}$ & $\mathbf{C l}^{-}$ & \\
\hline 864 & 5.72 & 2.02 & 7.27 & 0.38 & 0.28 & 2.68 & 4.03 & 8.4 & 3.43 \\
\hline
\end{tabular}

\subsection{Measurement of Vegetative Growth}

The Silybum plants were harvested at 270 days after sowing. The growth parameters such as plant height $(\mathrm{cm})$, number of leaves (n), number of branches (n), and respective dry weights of the aerial part $(\mathrm{g})$ and roots $(\mathrm{g})$ from 20 plants of each treatment group (sub-plot) were recorded.

\subsection{Measurement of Yield}

Mature fruits were harvested regularly from all of the plants and dried at room temperature. The number of capitula (n) and dry weight of fruits (g) from 20 plants of each treatment group (sub-plot) were documented.

\subsection{Determination of Photosynthetic Pigments}

The plant pigments (chlorophyll a (Chl-a), chlorophyll b (Chl-b), and carotenoid) were extracted from the third fresh leaf from the top of 20 randomly selected 270-day-old S. marianum plants of each treatment group (sub-plot) using $80 \%$ acetone. The pigment contents were measured spectrophotometrically and quantified as milligrams per $100 \mathrm{~g}$ of fresh leaf weight [22].

\subsection{Determination of Mineral Composition}

For each treatment group (sub-plot), the leaf samples from 20 randomly selected plants that were harvested at 270 days were dried at $60^{\circ} \mathrm{C}$ in an oven for $24 \mathrm{~h}$. The oven-dried leaves samples were ground and digested with sulfuric acid [23], and the potassium $\left(\mathrm{K}^{+}\right)$ and sodium $\left(\mathrm{Na}^{+}\right)$contents were determined by Atomic Absorption Flame Photometry [24].

2.9. Determination of Silybin $(A+B)$ Content by High-Performance Liquid Chromatography (HPLC) 2.9.1. Instrumentation

The HPLC analysis was performed using the Waters ${ }^{\mathrm{TM}} 2690$ Alliance HPLC system (Waters, Milford, MA, USA) equipped with a Waters ${ }^{\mathrm{TM}} 996$ photodiode array detector (Waters, Milford, MA, USA).

\subsubsection{Preparation of Silybin $(A+B)$ Standard Curve}

The silybin (A + B) authentic standard (93.06\%) (catalogue no. sc-473918) was purchased from the Santa Cruz Biotechnology, Dallas, TX, USA. A stock solution of $1 \mathrm{mg} / \mathrm{mL}$ of silybin $(\mathrm{A}+\mathrm{B})$ in methanol was prepared and diluted to obtain standard solutions with $750,500,250,100$, and $50 \mu \mathrm{g} / \mathrm{mL}$. All standard solutions were filtered using $0.22 \mu \mathrm{m}$ syringe filters, and $10 \mu \mathrm{L}$ of each standard solution was injected into the HPLC system per run. 


\subsubsection{Preparation of Silybum Fruit Methanolic Extract}

The contents of silybin $(A+B)$ were determined from the air-dried fruit samples collected from 20 plants per each treatment group (sub-plot). The air-dried fruits were ground with a blender, and the powders were used to perform the methanolic extraction. The known weight of the fruit powder was combined with $50 \mathrm{~mL}$ of methanol in a conical flask, sonicated for $30 \mathrm{~min}$, and kept in the dark for $24 \mathrm{~h}$. These processes (sonication for $30 \mathrm{~min}$ followed by maintenance in the dark for $24 \mathrm{~h}$ ) were repeated for two subsequent days by collecting the supernatant and by adding another $50 \mathrm{~mL}$ of fresh methanol to ensure complete extraction. All of the methanol supernatants collected from each sample for three consecutive days were combined and placed in a rotary evaporator operated at $40{ }^{\circ} \mathrm{C}$ to remove the solvent completely. A known weight of the residue (methanolic extract) was then dissolved in $5 \mathrm{~mL}$ of methanol, and the solution was filtered using a $0.22 \mu \mathrm{m}$ syringe filter. For each sample, $10 \mu \mathrm{L}$ of filtrate was injected into the HPLC system.

\subsubsection{HPLC Analysis Conditions}

The HPLC separation and quantitation were performed at ambient temperature with a C18 Kromasil ( $4.6 \mathrm{~mm} \times 150 \mathrm{~mm}, 5 \mu \mathrm{m}$ ) column (Waters, Milford, MA, USA). A gradient mobile phase was generated by systematically varying the mixture percentage of two solvents (A and B) throughout the operation $(50 \mathrm{~min})$. Solvent A consisted of water, methanol, and phosphoric acid (80:20:0.5), while solvent B consisted of methanol, water, and phosphoric acid (80:20:0.5). The flow rate was maintained at $1 \mathrm{~mL} / \mathrm{min}$. The eluted compounds were detected at $288 \mathrm{~nm}$.

\subsection{Analysis Chalcone Synthase 1, 2, and 3 Gene Expressions by Real-Time Reverse-Transcribed Polymerase Chain Reaction (Real Time RT-PCR)}

2.10.1. Total RNA Preparation and cDNA Synthesis

In each treatment group (sub-plot), the petals of 10 individual plants were collected and stored at $-80{ }^{\circ} \mathrm{C}$ until RNA extraction was performed using the RNeasy Mini Kit (Qiagen LLC, Hilden, Germany, catalogue. no. 74104). From each biological sample, $1 \mu \mathrm{g}$ of total RNA was reverse transcribed into cDNA using the ReadyScript ${ }^{\mathrm{TM}}$ cDNA synthesis mix (Sigma-Aldrich Inc. St. Louis, Missouri, USA, catalogue no. RDRT) following the manufacturers reaction conditions $\left(25^{\circ} \mathrm{C}\right.$ for $5 \mathrm{~min}, 42^{\circ} \mathrm{C}$ for $30 \mathrm{~min}$, and $85^{\circ} \mathrm{C}$ for $5 \mathrm{~min}$ ). The cDNA synthesis mix was supplied with a proprietary ratio of oligo-dT and random primers as determined by the manufacturer (ReadyScript ${ }^{\mathrm{TM}}$ ).

\subsubsection{Real-Time RT-PCR and Chalcone Synthase Gene Expression Analysis}

The real-time PCR reaction ( $25 \mu \mathrm{L}$ total volume) consisted of $2 \mu \mathrm{L}$ of the cDNA reaction mixture, a final concentration of $0.3 \mu \mathrm{M}$ of the respective forward and reverse primers (Table 3), $12.5 \mu \mathrm{L}$ of SYBR Green PCR Master Mix (QuantiTech SYBR Green PCR Kit, Qiagen LLC, Hilden, Germany, catalogue no. 204143), $1 \mu \mathrm{L}$ of the RNase inhibitor, and an appropriate volume of RNase-free water. The forward and reverse primers for the three target genes-chalcone synthase 1 (CHS1), chalcone synthase 2 (CHS2), and chalcone synthase 3 (CHS3) - and a reference gene, dehydrogenase (NADH), were designed according to the gene sequences available in GenBank (Table 3). The real-time PCR $\left(95^{\circ} \mathrm{C}\right.$ initial heating for $10 \mathrm{~min}$, and 45 cycles of $95^{\circ} \mathrm{C}$ for $20 \mathrm{~s}$ and $60^{\circ} \mathrm{C}$ for $1 \mathrm{~min}$ ) was performed using the Applied Biosystem 7500 Real-time PCR system (Termo Fisher Scientific, Waltham Massachusetts, USA). The expression of the individual chalcone synthase gene was quantified using the $2^{-\triangle \Delta C T}$ method [25] by normalizing the target gene expression with that of the reference gene. The mean expressions of each of the three CHS genes from every treatment group were calculated based on six biological samples, with two technical replicates from each biological sample. The relative fold expressions of the CHS1, CHS2, and CHS3 genes for individual treatment groups were calculated and compared with the expression of the corresponding gene for the control group (control salinity and MLE). 
Table 3. Sequences of forward and reverse primers for real-time RT-PCR.

\begin{tabular}{|c|c|c|c|}
\hline Gene & Primer's Sequence & Amplicon Length (bp) & GenBank Accession Number \\
\hline $\begin{array}{l}\text { Chalcone synthase1 } \\
\text { (CHS1) }\end{array}$ & $\begin{array}{c}\text { CHS1F } \\
\text { 5-TCTTGATTCCCTCGTTGGTC-3 } \\
\text { CHS1R 5- } \\
\text { TCTCAAACAACGGCCTCTCT-3 }\end{array}$ & 101 & JN182805.1 \\
\hline $\begin{array}{c}\text { Chalcone synthase } 2 \\
\text { (CHS2) }\end{array}$ & $\begin{array}{c}\text { CHS2F 5- } \\
\text { AGGACATTGCGGAAAACAAC-3 } \\
\text { CHS2R 5- } \\
\text { AACGGCCTCTCTGTCTTCAA-3 }\end{array}$ & 184 & JN182806.1 \\
\hline $\begin{array}{c}\text { Chalcone synthase3 } \\
\text { (CHS3) }\end{array}$ & $\begin{array}{c}\text { CHS3F } \\
\text { 5-ACCCACCTCATCTTTTGCAC-3 } \\
\text { CHS3R 5- } \\
\text { CATCATGAGGCGTTTGATTG-3 }\end{array}$ & 105 & JN182807.1 \\
\hline $\mathrm{NADH}$ & $\begin{array}{c}\text { ndhchs_L } \\
\text { 5-TTCCGCATTTTGGAAATACC-3 } \\
\text { ndhchs_R 5- } \\
\text { CCCGTCTTGATTGAAAGGAA-3 }\end{array}$ & 134 & KC589999.1 \\
\hline
\end{tabular}

\subsection{Statistical Analysis}

The experiment was conducted with a split-plot design and three whole plots (control, $2000 \mathrm{ppm}$, and $4000 \mathrm{ppm}$ salinity) and three sub-plots (control, $5 \mathrm{~g} / \mathrm{L}$, and $10 \mathrm{~g} / \mathrm{L}$ MLE). The data were statistically analyzed using Statistica 6 program ANOVA/MANOVA [26]. The significance of differences among means was detected using the Least Significant Test (L.S.D) at $p<0.05$.

\section{Results}

\subsection{Analysis of Moringa Oleifera Leaf Composition}

The chemical composition of the Moringa oleifera leaves is displayed in Table 1. The moringa leaves are rich in macro and micro elements $(\mathrm{Ca}, \mathrm{Cu}, \mathrm{Fe}, \mathrm{Mg}, \mathrm{P}, \mathrm{K}$, and $\mathrm{Zn}$ ); proteins; free amino acids (Arg, His, Ile, Leu, Lys, Met, Phe, Thr, Trp, and Val); vitamins (A, B1, B2, B3, and C); phytohormones (gibberellin, zeatin, and indole acetic acid); and secondary metabolites such as polyphenol, flavonoid, tocopherol, rutin, and gallic acid.

\subsection{The Effects of Salinity and MLE Foliar Spray on the Growth and Yield of Silybum Marianum}

The analyses of the salinity and MLE foliar treatment effects on the growth and yield parameters of Silybum marianum during both the 2018 and 2019 planting seasons are presented in Tables 4 and 5, respectively. The single factor analyses of the salinity treatments implied that an increase in salinity reduced all of the growth parameters in dosedependent manners during both planting seasons (Table 4a). The single factor analyses of the MLE foliar treatments indicated that both MLE concentrations $(5 \mathrm{~g} / \mathrm{L}$ and $10 \mathrm{~g} / \mathrm{L})$ positively impacted the plant height, number of leaves, number of branches, and aerial part dry weight (Table $4 \mathrm{~b}$ ). In both planting seasons, the $10 \mathrm{~g} / \mathrm{L}$ MLE performed better than the $5 \mathrm{~g} / \mathrm{L}$ MLE in all of the above parameters except for the number of branches. In contrast with all of the growth parameters mentioned above, the root dry weight was negatively affected by the MLE foliar treatments. 


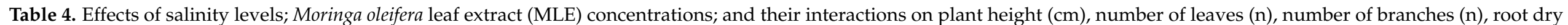
weight (g), and aerial part dry weight of S. marianum plants during the 2018 and 2019 planting seasons.

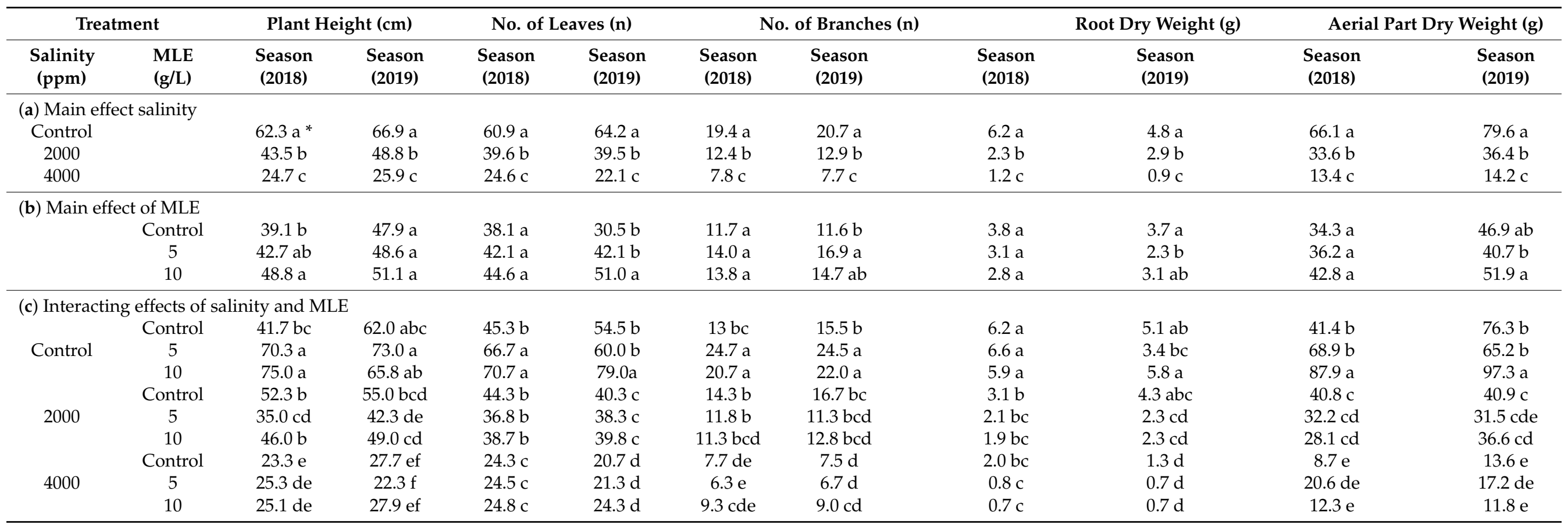

* Means followed by the same letter within a column are not significantly different at the 0.05 level of probability according to the L.S.D. test. 
Table 5. Effects of salinity levels, Moringa oleifera leaf extract (MLE) concentrations, and their interactions on S. marianum capitula number (n) and fruit dry weight (g) during the 2018 and 2019 planting seasons.

\begin{tabular}{|c|c|c|c|c|c|}
\hline \multicolumn{2}{|c|}{ Treatment } & \multicolumn{2}{|c|}{ Capitula Number (n) } & \multicolumn{2}{|c|}{ Fruit Dry Weight (g) } \\
\hline $\begin{array}{l}\text { Salinity } \\
\text { (ppm) }\end{array}$ & $\begin{array}{l}\text { MLE } \\
\text { (g/L) }\end{array}$ & $\begin{array}{c}\text { Season } \\
(2018)\end{array}$ & $\begin{array}{c}\text { Season } \\
\text { (2019) }\end{array}$ & $\begin{array}{c}\text { Season } \\
(2018)\end{array}$ & $\begin{array}{c}\text { Season } \\
(2019)\end{array}$ \\
\hline \multicolumn{6}{|c|}{ (a) Main effect of salinity } \\
\hline Control & & $18.3 \mathrm{a} *$ & $14.3 \mathrm{a}$ & $38.8 \mathrm{a}$ & $41.8 \mathrm{a}$ \\
\hline 2000 & & $17.6 \mathrm{ab}$ & $14.2 \mathrm{a}$ & $23.5 \mathrm{~b}$ & $24.4 \mathrm{~b}$ \\
\hline 4000 & & $9.0 \mathrm{~b}$ & $12.9 \mathrm{a}$ & $9.3 \mathrm{c}$ & $4.5 \mathrm{c}$ \\
\hline \multicolumn{6}{|c|}{ (b) Main effect of MLE } \\
\hline & Control & $14.3 \mathrm{a}$ & $11.7 \mathrm{~b}$ & $22.6 \mathrm{a}$ & $33.9 \mathrm{a}$ \\
\hline & 5 & $14.8 \mathrm{a}$ & $12.1 \mathrm{~b}$ & $25.7 \mathrm{a}$ & $20.9 \mathrm{~b}$ \\
\hline & 10 & $17.9 \mathrm{a}$ & $16.9 \mathrm{a}$ & $23.2 \mathrm{a}$ & $25.8 \mathrm{~b}$ \\
\hline \multicolumn{6}{|c|}{ (c) Interacting effects of salinity and MLE } \\
\hline & control & $16.3 \mathrm{abc}$ & $13.7 \mathrm{ab}$ & $28.4 \mathrm{c}$ & $52.9 \mathrm{a}$ \\
\hline \multirow{3}{*}{ control } & 5 & $19.0 \mathrm{ab}$ & $11.0 \mathrm{~b}$ & $49.4 \mathrm{a}$ & $31.1 \mathrm{bc}$ \\
\hline & 10 & $21.5 \mathrm{a}$ & $17.7 \mathrm{a}$ & $38.9 \mathrm{~b}$ & $41.4 \mathrm{~b}$ \\
\hline & control & $14.3 \mathrm{abc}$ & $11.7 \mathrm{ab}$ & $28.0 \mathrm{c}$ & $28.7 \mathrm{c}$ \\
\hline \multirow[t]{3}{*}{2000} & 5 & $16.0 \mathrm{abc}$ & $13 \mathrm{ab}$ & $22.1 \mathrm{c}$ & $21.3 \mathrm{~cd}$ \\
\hline & 10 & $21.0 \mathrm{a}$ & $16.7 \mathrm{ab}$ & $20.9 c$ & $23.6 \mathrm{~cd}$ \\
\hline & control & $12.3 \mathrm{bc}$ & $10.3 \mathrm{~b}$ & $11.7 \mathrm{~d}$ & $13.8 \mathrm{de}$ \\
\hline \multirow[t]{2}{*}{4000} & 5 & $9.0 \mathrm{c}$ & $12.5 \mathrm{ab}$ & $6.5 \mathrm{~d}$ & $6.8 \mathrm{e}$ \\
\hline & 10 & $11.3 \mathrm{bc}$ & $10.0 \mathrm{~b}$ & $9.8 \mathrm{~d}$ & $7.8 \mathrm{e}$ \\
\hline
\end{tabular}

* Means followed by the same letter within a column are not significantly different at the 0.05 level of probability according to the L.S.D. test.

When the effects of both the salinity and MLE treatments were analyzed together, the enhancement effects of MLE foliar treatments on plant height, number of leaves, and number of branches were only obvious at control salinity. In addition, the negative impact of MLE on root dry weight observed in the single factor data analysis appeared to result from the influence of salt stress as reduced root dry weight trends were only observed in plants irrigated with 2000 and 4000 ppm saline but not in those irrigated with tap water (control salinity). At moderate salinity levels (2000 ppm), the application of MLE reduced all of the growth parameters (plant height, number of leaves, number of branches, root dry weight, and aerial part dry weight) of $S$. marianum. As expected, the plant height, number of leaves, and number of branches were greatly reduced at high salinity levels (4000 ppm) compared with those cultivated at control and moderate (2000 ppm) salinity. The application of either 5 or $10 \mathrm{~g} / \mathrm{L}$ of MLE to plants cultivated at high salinity (4000 ppm) resulted in huge enhancements in aerial parts dry weight. In addition, increases in the number of leaves and branches were also observed in plants sprayed with $10 \mathrm{~g} / \mathrm{L}$ MLE (Table 4c).

A single factor analysis of the salinity treatment indicated that salinity decreased the number of capitula as well as the dry weight of fruits in both planting seasons (Table 5a). Single factor analyses of the MLE treatments indicated that MLE increased the number of capitula in both the 2018 and 2019 planting seasons, with the $10 \mathrm{~g} / \mathrm{L}$ MLE treatment giving the highest number of capitula. The effects of MLE on the fruit dry weight were different in the two planting seasons. In 2018, the MLE was found to increase the fruit dry weight, though not statistically significantly. However, in 2019, the MLE was found to decrease the fruit dry weight (Table 5b).

Analyses of interaction effects between MLE and salinity treatments revealed that the MLE treatments increased the number of capitula at control and moderate salinity (2000 ppm), with $10 \mathrm{~g} / \mathrm{L}$ MLE producing the highest number of capitula in both seasons. At high salinity (4000 ppm), the results were inconsistent, as in 2018, the presence of MLE was found to reduce the number of capitula, while in another season, the $5 \mathrm{~g} / \mathrm{L}$ MLE increased the number of capitula. Under moderate (2000 ppm) and high (4000 ppm) salinity, the 
presence of MLE lowered the fruit dry weight in both planting seasons; however, under control salinity, the MLE effect was contradictory between seasons. For instance, in 2018, the application of MLE to plants cultivated under control salinity have higher fruit dry weight, but the reverse was observed in 2019 (Table 5c).

3.3. The Effects of Salinity and MLE Foliar Spray on the Compositions of Chlorophyll a, Chlorophyll $b$, and Carotenoid in S. marianum Leaves

Single factor analyses of the salinity effect showed a consistent reduction in the chlorophyll $\mathrm{b}$ contents in both planting seasons (Table 6a). On the other hand, single factor analyses of the MLE effects on the photosynthetic pigment (chlorophyll a (Chl a), chlorophyll b (Chl b), and carotenoids) contents in the S. marianum leaves revealed that the application of MLE reduced the contents of $\mathrm{Chl}$ a and carotenoid in both planting seasons (Table 6b).

Table 6. Effects of salinity levels, Moringa oleifera leaf extract (MLE) concentrations, and their interactions on the compositions ( $\mathrm{mg} / 100 \mathrm{~g}$ fresh weight of leaves) of chlorophyll a (Chl a), chlorophyll b (Chl b), and carotenoids in S. marianum leaf samples during the 2018 and 2019 planting seasons.

\begin{tabular}{|c|c|c|c|c|c|c|c|}
\hline \multicolumn{2}{|c|}{ Treatment } & \multicolumn{2}{|c|}{$\begin{array}{c}\text { Chl a } \\
(\mathrm{mg} / 100 \mathrm{~g} \mathrm{F.W.})\end{array}$} & \multicolumn{2}{|c|}{$\begin{array}{c}\text { Chl b } \\
\text { (mg/100 g F.W.) }\end{array}$} & \multicolumn{2}{|c|}{$\begin{array}{l}\text { Carotenoids } \\
\text { (mg/100 g F.W.) }\end{array}$} \\
\hline $\begin{array}{l}\text { Salinity } \\
\text { (ppm) }\end{array}$ & $\begin{array}{l}\text { MLE } \\
(\mathrm{g} / \mathrm{L})\end{array}$ & $\begin{array}{c}\text { Season } \\
(2018)\end{array}$ & $\begin{array}{l}\text { Season } \\
(2019)\end{array}$ & $\begin{array}{l}\text { Season } \\
(2018)\end{array}$ & $\begin{array}{c}\text { Season } \\
(2019)\end{array}$ & $\begin{array}{l}\text { Season } \\
(2018)\end{array}$ & $\begin{array}{c}\text { Season } \\
(2019)\end{array}$ \\
\hline \multicolumn{8}{|c|}{ (a) Main effect of salinity } \\
\hline Control & & $89.69 a^{*}$ & $92.46 \mathrm{a}$ & $24.41 \mathrm{a}$ & $26.20 \mathrm{a}$ & $85.46 \mathrm{a}$ & $89.05 \mathrm{a}$ \\
\hline 2000 & & 86.94 a & $93.10 \mathrm{a}$ & $23.35 \mathrm{a}$ & $25.28 \mathrm{a}$ & $86.42 a$ & $91.47 \mathrm{a}$ \\
\hline 4000 & & $87.53 \mathrm{a}$ & $86.72 \mathrm{a}$ & $23.52 \mathrm{a}$ & $23.37 \mathrm{a}$ & $87.38 \mathrm{a}$ & $87.23 \mathrm{a}$ \\
\hline \multicolumn{8}{|c|}{ (b) Main effect of MLE } \\
\hline & Control & $94.44 \mathrm{a}$ & $92.97 \mathrm{a}$ & $25.47 \mathrm{a}$ & $25.03 \mathrm{a}$ & $91.56 \mathrm{a}$ & $91.15 \mathrm{a}$ \\
\hline & 5 & $86.70 \mathrm{a}$ & 86.66 a & $23.38 \mathrm{a}$ & $23.81 \mathrm{a}$ & $86.29 \mathrm{a}$ & $86.94 \mathrm{a}$ \\
\hline & 10 & $83.02 \mathrm{a}$ & $92.65 \mathrm{a}$ & $22.43 \mathrm{a}$ & $26.00 \mathrm{a}$ & $81.40 \mathrm{a}$ & 89.67 a \\
\hline \multicolumn{8}{|c|}{ (c) Interacting effects of salinity and MLE } \\
\hline & Control & $109.96 \mathrm{a}$ & $93.93 \mathrm{a}$ & $29.57 \mathrm{a}$ & $26.30 \mathrm{a}$ & $85.02 \mathrm{ab}$ & 89.62 a \\
\hline \multirow[t]{3}{*}{ Control } & 5 & $89.26 \mathrm{ab}$ & $93.14 \mathrm{a}$ & $24.18 \mathrm{ab}$ & $27.08 \mathrm{a}$ & $84.90 \mathrm{ab}$ & $91.99 \mathrm{a}$ \\
\hline & 10 & $69.86 \mathrm{~b}$ & $90.32 \mathrm{a}$ & $19.27 b$ & $25.21 \mathrm{a}$ & $67.17 \mathrm{~b}$ & $85.53 \mathrm{a}$ \\
\hline & Control & $87.76 \mathrm{ab}$ & $104.12 \mathrm{a}$ & $23.52 \mathrm{ab}$ & $27.98 \mathrm{a}$ & $90.31 \mathrm{a}$ & $101.67 \mathrm{a}$ \\
\hline \multirow[t]{3}{*}{2000} & 5 & $79.27 \mathrm{~b}$ & $77.52 \mathrm{a}$ & $21.12 \mathrm{ab}$ & $19.82 \mathrm{a}$ & $81.41 \mathrm{ab}$ & $78.12 \mathrm{a}$ \\
\hline & 10 & $93.79 \mathrm{ab}$ & $97.65 \mathrm{a}$ & $25.41 \mathrm{ab}$ & $28.03 \mathrm{a}$ & $92.47 \mathrm{a}$ & $94.63 \mathrm{a}$ \\
\hline & Control & $85.59 \mathrm{ab}$ & $80.86 \mathrm{a}$ & $23.32 \mathrm{ab}$ & $20.81 \mathrm{a}$ & $85.37 \mathrm{ab}$ & $85.53 \mathrm{a}$ \\
\hline \multirow[t]{2}{*}{4000} & 5 & $91.58 \mathrm{ab}$ & 89.32 a & $24.83 \mathrm{ab}$ & $24.54 \mathrm{a}$ & $92.54 \mathrm{ab}$ & $90.62 \mathrm{a}$ \\
\hline & 10 & $85.42 \mathrm{ab}$ & 89.99 a & $22.39 \mathrm{ab}$ & $24.78 \mathrm{a}$ & $84.58 \mathrm{ab}$ & $88.85 \mathrm{a}$ \\
\hline
\end{tabular}

${ }^{*}$ Means followed by the same letter within a column are not significantly different at the 0.05 level of probability according to the L.S.D. test.

Analyses of the interaction effects of salinity and MLE indicated that, under control salinity, the presence of MLE reduced the $\mathrm{Chl} \mathrm{a}, \mathrm{Chl} b$, and carotenoid contents significantly in the 2018 season. Even though increases in $\mathrm{Chl} \mathrm{b}$ and carotenoid contents were observed in plants sprayed with $5 \mathrm{~g} / \mathrm{L}$ MLE in the 2019 season, the difference was not statistically different from those of the control (without MLE) and the $10 \mathrm{~g} / \mathrm{L}$ MLE groups. In the 2018 planting season, the application of $5 \mathrm{~g} / \mathrm{L}$ MLE to plants grown at moderate salinity $(2000 \mathrm{ppm})$ significantly reduced the contents of $\mathrm{Chl}$ a and carotenoid, while the application of $10 \mathrm{~g} / \mathrm{L}$ MLE increased the contents of these pigments even though the differences were not statistically different from those of the control (without MLE). A similar trend (decreased by $5 \mathrm{~g} / \mathrm{L}$ MLE but increased by $10 \mathrm{~g} / \mathrm{L}$ MLE) was also observed in the chlorophyll $\mathrm{b}$ contents, even though the difference among the means was not statistically significant. At high salinity (4000 ppm), the presence of $5 \mathrm{~g} / \mathrm{L}$ MLE elevated the carotenoid contents in both planting seasons. However, the effects of MLE on Chl a and Chl b were contradictory between the two planting seasons (Table 6c). 


\subsection{The Effects of Salinity and MLE Foliar Spray on the Mineral Contents in S. marianum Leaves}

The sole effects of salinity were very clear. An increase in salinity resulted in an increased sodium content but a reduced potassium content (Table 7a). In contrast with that of salinity, the sole effects of MLE on the sodium or potassium contents in S. marianum leaves were inconsistent between the two planting seasons. In the 2018 planting season, increases in $\mathrm{Na}^{+}$content and reductions in $\mathrm{K}^{+}$content were associated with the application of MLE. On the other hand, in the 2019 planting season, the application of $10 \mathrm{~g} / \mathrm{L}$ MLE increased both $\mathrm{Na}^{+}$and $\mathrm{K}^{+}$in the plant leaves (Table $7 \mathrm{~b}$ ).

Table 7. Effects of salinity levels, Moringa oleifera leaf extract (MLE) concentrations, and their interactions on the percentages of sodium $\left(\% \mathrm{Na}^{+}\right)$and potassium $\left(\% \mathrm{~K}^{+}\right)$in S. marianum leave samples during the 2018 and 2019 planting seasons.

\begin{tabular}{|c|c|c|c|c|c|}
\hline \multicolumn{2}{|c|}{ Treatment } & \multicolumn{2}{|c|}{$\% \mathrm{Na}^{+}$} & \multicolumn{2}{|c|}{$\% \mathrm{~K}^{+}$} \\
\hline $\begin{array}{c}\text { Salinity } \\
\text { (ppm) }\end{array}$ & $\begin{array}{l}\text { MLE } \\
(\mathrm{g} / \mathrm{L})\end{array}$ & $\begin{array}{c}\text { Season } \\
(2018)\end{array}$ & $\begin{array}{c}\text { Season } \\
(2019)\end{array}$ & $\begin{array}{c}\text { Season } \\
(2018)\end{array}$ & $\begin{array}{c}\text { Season } \\
(2019)\end{array}$ \\
\hline \multicolumn{6}{|c|}{ (a) Main effect of salinity } \\
\hline Control & & $0.212 c^{*}$ & $0.187 \mathrm{c}$ & $1.139 \mathrm{a}$ & $0.975 \mathrm{a}$ \\
\hline 2000 & & $0.329 \mathrm{~b}$ & $0.389 \mathrm{~b}$ & $0.696 b$ & $0.608 \mathrm{~b}$ \\
\hline 4000 & & $0.538 \mathrm{a}$ & $0.532 \mathrm{a}$ & $0.420 \mathrm{c}$ & $0.440 \mathrm{c}$ \\
\hline \multicolumn{6}{|c|}{ (b) Main effect of MLE } \\
\hline & Control & $0.334 \mathrm{~b}$ & $0.372 \mathrm{a}$ & $0.880 \mathrm{a}$ & $0.663 \mathrm{a}$ \\
\hline & 5 & $0.394 \mathrm{a}$ & $0.360 \mathrm{a}$ & $0.673 \mathrm{~b}$ & $0.673 \mathrm{a}$ \\
\hline & 10 & $0.351 \mathrm{~b}$ & $0.376 \mathrm{a}$ & $0.703 \mathrm{~b}$ & $0.686 \mathrm{a}$ \\
\hline \multicolumn{6}{|c|}{ (c) Interacting effects of salinity and MLE } \\
\hline & Control & $0.216 \mathrm{c}$ & $0.179 \mathrm{~d}$ & $1.488 \mathrm{a}$ & $1.103 \mathrm{a}$ \\
\hline \multirow[t]{3}{*}{ Control } & 5 & $0.244 \mathrm{c}$ & $0.223 \mathrm{~d}$ & $0.818 \mathrm{c}$ & $0.828 \mathrm{~b}$ \\
\hline & 10 & $0.176 \mathrm{c}$ & $0.158 \mathrm{~d}$ & $1.113 \mathrm{~b}$ & $0.995 \mathrm{a}$ \\
\hline & Control & $0.222 \mathrm{c}$ & 0.404 c & $0.759 \mathrm{~cd}$ & $0.483 \mathrm{~cd}$ \\
\hline \multirow[t]{3}{*}{2000} & 5 & $0.411 \mathrm{~b}$ & $0.366 \mathrm{c}$ & $0.739 \mathrm{~cd}$ & $0.759 \mathrm{~b}$ \\
\hline & 10 & $0.355 \mathrm{~b}$ & $0.399 \mathrm{c}$ & $0.591 \mathrm{de}$ & $0.581 \mathrm{c}$ \\
\hline & Control & $0.561 \mathrm{a}$ & $0.571 \mathrm{a}$ & $0.394 \mathrm{f}$ & $0.404 \mathrm{~d}$ \\
\hline \multirow[t]{2}{*}{4000} & 5 & $0.528 \mathrm{a}$ & $0.493 \mathrm{~b}$ & $0.463 \mathrm{ef}$ & $0.433 \mathrm{~d}$ \\
\hline & 10 & $0.520 \mathrm{a}$ & $0.532 \mathrm{ab}$ & 0.404 ef & $0.483 \mathrm{~cd}$ \\
\hline
\end{tabular}

${ }^{*}$ Means followed by the same letter within a column are not significantly different at the 0.05 level of probability according to the L.S.D. test.

The combined effects of MLE and salinity were complex. Nevertheless, in control and high salinity (4000 ppm), plants with the highest sodium contents were found to have the lowest potassium contents. For instance, in the control salinity treatment, plants treated with $5 \mathrm{~g} / \mathrm{L}$ MLE contained the highest sodium but lowest potassium contents compared with the control (without MLE) and $10 \mathrm{~g} / \mathrm{L}$ MLE-treated plants. Similarly, under high salinity (4000 ppm), the plants treated with control (without MLE) also contained the highest sodium but lowest potassium contents compared with those treated with either concentration of MLE. In general, we observed that plants cultivated under $4000 \mathrm{ppm}$ salinity accumulated less $\mathrm{Na}^{+}$but more $\mathrm{K}^{+}$if they were treated with MLE foliar spray (Table 7c).

3.5. The Effects of Salinity and MLE Foliar Spray on the Total Amount of Methanolic Extract and Silybin $(A+B)$ Composition of S. marianum Fruits

The combined effects of salinity and MLE on the production of secondary metabolites in S. marianum were investigated (Table 8, Figure 1). Methanolic extracts were prepared from the ground, air-dried fruits of $S$. marianum plants treated with various combinations of salinity levels and concentrations of MLE. The amounts of silybin (A + B) present in the methanolic extracts were quantified using high-performance liquid chromatography (HPLC) by comparing the standard curve prepared using a series of silybin $(A+B)$ solutions with known concentrations. 
Table 8. Effects of the interactions of salinity levels and Moringa oleifera leaf extract (MLE) concentrations on the total amount of methanolic extracts (grams per $100 \mathrm{~g}$ of fruits in dry weight) and silybin $(\mathrm{A}+\mathrm{B})$ compositions (milligrams per gram of extract) from S. marianum fruit samples during the 2018 planting season.

\begin{tabular}{cccc}
\hline \multicolumn{2}{c}{ Treatment } & $\begin{array}{c}\text { Total Methanolic } \\
\text { Extract (g/100 g D.W.) }\end{array}$ & $\begin{array}{c}\text { Silybin (A + B) } \\
\text { Composition (mg/g Extract) }\end{array}$ \\
\hline \multirow{2}{*}{ Salinity (ppm) } & MLE (g/L) & $13.421 \mathrm{~d}^{*}$ & $1.056 \mathrm{a}$ \\
& Control & $13.910 \mathrm{~d}$ & $2.262 \mathrm{~cd}$ \\
& 5 & $12.560 \mathrm{~cd}$ & $1.796 \mathrm{bc}$ \\
\hline \multirow{2}{*}{2000} & 10 & $23.614 \mathrm{a}$ & $1.578 \mathrm{~d}$ \\
& Control & $21.960 \mathrm{~b}$ & $1.444 \mathrm{c}$ \\
& 5 & $18.620 \mathrm{bc}$ & $1.279 \mathrm{~b}$ \\
\hline \multirow{2}{*}{4000} & 10 & $21.240 \mathrm{~b}$ & $1.119 \mathrm{~b}$ \\
& Control & $21.261 \mathrm{~b}$ & $1.148 \mathrm{~b}$ \\
& 5 & $20.790 \mathrm{~b}$ & $0.926 \mathrm{a}$ \\
\hline
\end{tabular}

* Means followed by the same letter within a column are not significantly different at the 0.05 level of probability according to the L.S.D. test.
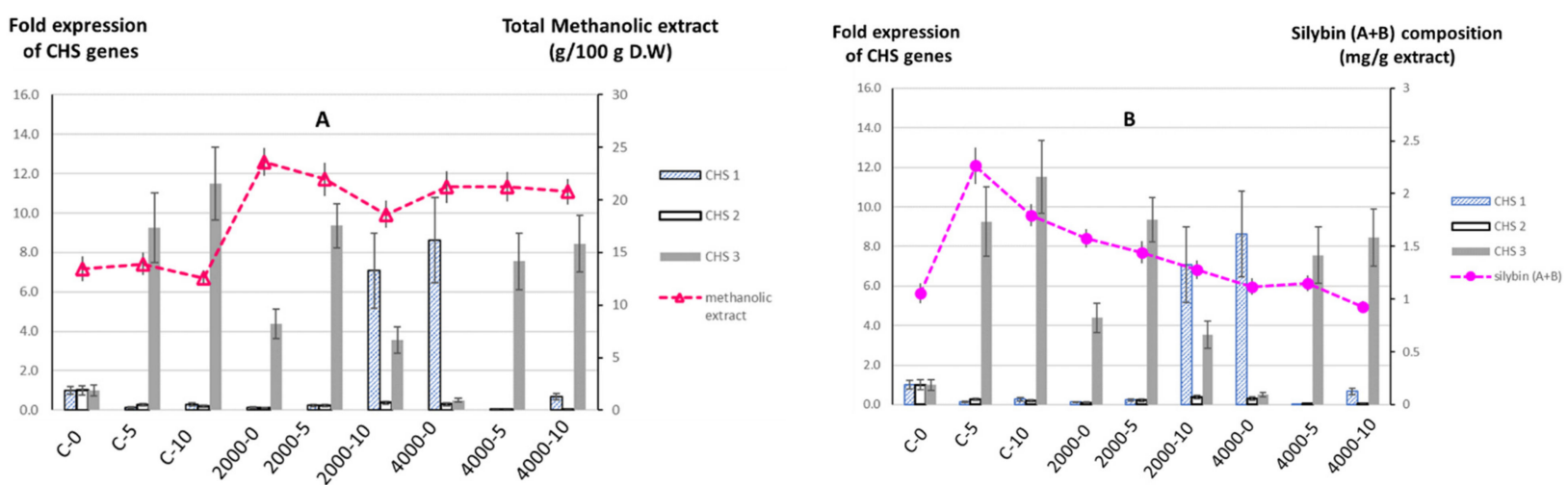

Figure 1. The fold expressions of chalcone synthase (CHS) genes in relation to total methanolic extract (A) and silybin $(\mathrm{A}+\mathrm{B})$ composition (B). The expressions of CHS1, CHS2, and CHS3 for control salinity, without MLE foliar spray (C-0), were normalized as 1 . The expressions of the CHS genes for all other treatments (C-5, C-10, 2000-0, 2000-5, 2000-10, 4000-0, 4000-5, and 4000-10) were expressed as fold expressions with respect to the expressions of corresponding genes for C-0 treatment. The amount of methanolic extract was expressed as grams of extract per $100 \mathrm{~g}$ of fruit by dry weight, while the silybin composition was measured using high-performance liquid chromatography (HPLC) and expressed as milligrams of silybin $(\mathrm{A}+\mathrm{B})$ per gram of methanolic extract. The $+/-$ bar on the graphs represents the standard error of the corresponding measurement.

As expected, salinity as an abiotic stress factor increased the total methanolic extract as well as the silybin $(\mathrm{A}+\mathrm{B})$ composition. The highest amounts of methanolic extract and silybin $(\mathrm{A}+\mathrm{B})$ composition were observed in plants cultivated under moderate salinity (2000 ppm) without MLE foliar spray. The $2000 \mathrm{ppm}$ salinity led to the accumulation of the highest amount of extract $(23.614 \mathrm{~g} / 100 \mathrm{~g} \mathrm{D} . \mathrm{W})$ from the dried fruit compared with those plants grown under 4000 ppm (21.240 g/100 g D.W ) or control salinity (13.421 g/100 g D.W). In addition, the corresponding extract also contained the highest composition of silybin $(\mathrm{A}+\mathrm{B})(1.578 \mathrm{mg} / \mathrm{g}$ extract $)$ compared to extracts from plants grown under 4000 ppm (1.119 g/100 g mg/g extract) or control salinity (1.056 g mg/g extract).

The effects of MLE foliar spray on the amount of total methanolic extracts produced and the composition of silybin $(A+B)$ were dependent on the salinity levels in which the plants were cultivated. For plants grown under control salinity, the application of MLE significantly increased the composition of silybin $(A+B)$ within the methanolic extract. The $5 \mathrm{~g} / \mathrm{L}$ MLE foliar spray induced the highest silybin $(\mathrm{A}+\mathrm{B})$ composition $(2.262 \mathrm{mg} / \mathrm{g}$ 
extract) compared with the $10 \mathrm{~g} / \mathrm{L}$ MLE (1.796 mg/g extract) or control $(1.056 \mathrm{mg} / \mathrm{g}$ extract) treatments. Interestingly, we observed no significant change in the total amount of methanolic extract when $5 \mathrm{~g} / \mathrm{L}$ MLE was applied, and a reduction in total amount of methanolic extract was observed when $10 \mathrm{~g} / \mathrm{L}$ MLE was applied. The application of MLE on plants grown under moderate salinity (2000 ppm) reduced the total amount of methanolic extract as well as the composition of silybin $(A+B)$ within the extracts compared with plants that were sprayed with the control (tap water). On the other hand, the application of MLE on plants grown under high (4000 ppm) salinity did not show any significant difference in the total amount of methanolic extract content. In addition, a small reduction in silybin $(A+B)$ composition was observed in the plants treated with $10 \mathrm{~g} / \mathrm{L}$ MLE.

3.6. The Effects of Salinity and MLE Foliar Spray on the Expressions of Chalcone Synthase 1, 2, and 3 Genes in S. marianum Petals

In this study, our results indicated that the CHS1 and CHS3 genes were upregulated differentially by salinity and/or MLE treatments. In contrast to the CHS1 and CHS3 genes, the CHS2 gene was downregulated in all of the treatments compared with the control (control salinity level and without MLE foliar spray). Approximately seven- to eightfold higher expression levels of the CHS1 gene were observed in combination treatments of $2000 \mathrm{ppm}$ salinity/10 g MLE and $4000 \mathrm{ppm}$ salinity/without MLE. All combinations of salinity and MLE treatments except that of $4000 \mathrm{ppm} /$ without MLE showed three- to elevenfold higher CHS3 gene expressions compared to the control (control salinity level and without MLE foliar sprayed) (Figure 1).

\section{Discussion}

The present study aimed to examine the combined effects of different concentrations of moringa leaf extract (MLE) and salinity levels on the vegetative growth, yield, and silybin $(\mathrm{A}+\mathrm{B})$ compositions of $S$. marianum plants. The increase in S. marianum plant growth and yield observed in plants cultivated without salinity stress (control salinity) supported previous reports from other plants species, which implies that MLE is a highly promising bio-stimulant [12-14,17,18,27]. Phytohormones such as indoleacetic acids (IAA), gibberellins, and zeatin, which promote cell division and cell expansion, have been associated with MLE-induced plant growth and yield enhancement [12]. In contract with many previous studies on other plant species, no MLE-induced enhancement effects were observed on the contents of photosynthetic pigments in the S. marianum leaves despite the increase in plant growth and yield. HPLC analyses revealed that the application of MLE foliar spray to plants cultivated under control salinity differentially affected the compositions of the methanolic extracts produced from the fruits of the treated plants. We observed that MLE increased the silybin (A + B) compositions without significantly altering the total amount of methanolic extract produced from these plants; $5 \mathrm{~g} / \mathrm{L}$ MLE produced the highest amount of silybin (A + B) compared with those without MLE spray or sprayed with $10 \mathrm{~g} / \mathrm{L}$ MLE. Taken together, our results suggest that the application of $10 \mathrm{~g} / \mathrm{L}$ MLE foliar spray has greater enhancement effects on the growth and yield of $S$. marianum while $5 \mathrm{~g} / \mathrm{L}$ MLE led to higher methanolic extract production and higher silybin $(A+B)$ compositions within the extract.

Decreased plant growth and yield have been widely reported in plants cultivated under saline conditions, as the plants diverted their resources to cope with stress. Consistent with previous investigations from S. marianum [8] and other plant species [28-30], salinityassociated reductions in growth and yield of $S$. marianum plants as well as their chlorophyll $\mathrm{a}$ and $\mathrm{b}$ contents were also noted in the present study. The salinity-induced adverse effects on the abovementioned parameters were mild under $2000 \mathrm{ppm}$ salinity but became severe when the salinity was raised to $4000 \mathrm{ppm}$. Elevated levels of carotenoid, a photosynthetic pigment, also play a critical antioxidant role [31] in easing the adverse effects caused by the accumulation of reactive oxygen species (ROS) in S. marianum plants grown under $2000 \mathrm{ppm}$ and $4000 \mathrm{ppm}$ salinity levels. As expected, S. marianum plants grown under 
higher salinity level accumulated a higher level of sodium salt but a comparatively lower level of potassium salts due to the competition between both type of salts for binding to the same type of ion transporter [32]. Similar to drought stress [33], the S. marianum plants increased the production of secondary metabolites, as seen in the increase amount of methanolic extract as well as in the composition of silybin $(A+B)$ within the extract in order to cope with salt stress.

The MLE enhancement effects on growth (number of leaves and branches, and arial part dry weight), yield (no. of capitula), and carotenoid contents observed in S. marianum plants grown under high salinity (4000 ppm) in the present investigation conformed to previous reports on numerous plant species grown under salinity [34-37] and other stresses $[15,36,38-40]$. Besides the above parameters, MLE foliar spray also reduced the accumulation of $\mathrm{Na}^{+}$ions while increasing $\mathrm{K}^{+}$ions in the cells of plants irrigated with 4000 ppm saline. Increases in $\mathrm{K}^{+}$and $\mathrm{Na}^{+}$have been associated with increases in the osmo-tolerance of plants exposed to salt stress [28]. Despite the positive impacts mentioned above, enhancements in both the amount of methanolic extract and the silybin $(\mathrm{A}+\mathrm{B})$ compositions in plants treated with $5 \mathrm{~g} / \mathrm{L}$ MLE were mild and statistically insignificant. In addition, decreases in the amount of methanolic extract and silybin $(\mathrm{A}+\mathrm{B})$ composition were observed in plants treated with $10 \mathrm{~g} / \mathrm{L}$ MLE. In summary, for plants irrigated with $4000 \mathrm{ppm}$ saline, $5 \mathrm{~g} / \mathrm{L}$ MLE has shown enhancement effects on the aerial part dry weight and carotenoid contents, while $10 \mathrm{~g} / \mathrm{L}$ MLE has shown improvements on the number of leaves and branches. For plants grown under 2000 ppm salinity, we did not observe any positive impacts of MLE on any of the growth parameters; moreover, MLE dose-dependent decreases in the total amount of methanolic extract and silybin $(\mathrm{A}+\mathrm{B})$ were also observed.

The concomitant upregulation of chalcone synthase (CHS 1 and 3) genes and total methanolic extract content and/or silybin $(\mathrm{A}+\mathrm{B})$ composition as observed in the current study were in accordance with previous reports [8,41-43] even though the roles of each CHS gene needs to be further elucidated.

\section{Conclusions}

Our results have revealed that, without salinity stress, the $10 \mathrm{~g} / \mathrm{L}$ MLE foliar application was optimal for growth, yield, and silybin (A + B) composition. The MLE foliar spray was able to reduce the salinity-induced adverse effects on the growth of $S$. marianum plants irrigated with $4000 \mathrm{ppm}$ saline but has little impact on those irrigated with $2000 \mathrm{ppm}$ saline. The application of MLE has either no significant impact or negative impact on the compositions of silybin $(A+B)$ in plants cultivated under 2000 ppm and 4000 ppm salinity.

Author Contributions: Conceptualization, Y.-K.Y., F.E.-S. and S.K.; methodology, Y.-K.Y. and F.E.-S.; formal analysis, Y.-K.Y., F.E.-S., S.K. and E.S.H.; data curation, Y.-K.Y. and F.E.-S.; writing-original draft preparation, F.E.-S.; writing-review and editing, Y.-K.Y.; All authors have read and agreed to the published version of the manuscript.

Funding: The authors extend their appreciations to the Deanship of Scientific Research, King Faisal University, for funding this research work through grant number 170108.

Institutional Review Board Statement: Not applicable.

Informed Consent Statement: Not applicable.

Data Availability Statement: Not applicable.

Acknowledgments: Assistance from the greenhouse staff at the Agriculture and Veterinary Research and Training Centre, King Faisal University, was highly appreciated.

Conflicts of Interest: The authors declare no conflict of interest. 


\section{References}

1. Jimenez-Garcia, S.N.; Vazquez-Cruz, M.A.; Guevara-Gonzalez, R.G.; Torres-Pacheco, I.; Cruz-Hernandez, A.; Feregrino-Perez, A.A. Current Approaches for Enhanced Expression of Secondary Metabolites as Bioactive Compounds in Plants for Agronomic and Human Health Purposes-A Review. Pol. J. Food Nutr. Sci. 2013, 63, 67-78. [CrossRef]

2. Crocenzi, F.; Roma, M. Silymarin as a New Hepatoprotective Agent in Experimental Cholestasis: New Possibilities for an Ancient Medication. Curr. Med. Chem. 2006, 13, 1055-1074. [CrossRef] [PubMed]

3. Biedermann, D.; Vavř́ková, E.; Cvak, L.; Křen, V. Chemistry of Silybin. Nat. Prod. Rep. 2014, 31, 1138-1157. [CrossRef]

4. Ou, Q.; Weng, Y.; Wang, S.; Zhao, Y.; Zhang, F.; Zhou, J.; Wu, X. Silybin Alleviates Hepatic Steatosis and Fibrosis in NASH Mice by Inhibiting Oxidative Stress and Involvement with the Nf-KB Pathway. Dig. Dis. Sci. 2018, 63, 3398-3408. [CrossRef] [PubMed]

5. Sun, R.; Xu, D.; Wei, Q.; Zhang, B.; Aa, J.; Wang, G.; Xie, Y. Silybin Ameliorates Hepatic Lipid Accumulation and Modulates Global Metabolism in an NAFLD Mouse Model. Biomed. Pharmacother. 2020, 123, 109721. [CrossRef]

6. Firouzi, A.; Mohammadi, S.A.; Khosrowchahli, M.; Movafeghi, A.; Hasanloo, T. Enhancement of Silymarin Production in Cell Culture of Silybum marianum (L) Gaertn by Elicitation and Precursor Feeding. J. Herbs Spices Med. Plants 2013, 19, $262-274$. [CrossRef]

7. Madrid, E.; Corchete, P.N. Silymarin Secretion and Its Elicitation by Methyl Jasmonate in Cell Cultures of Silybum marianum Is Mediated by Phospholipase D-Phosphatidic Acid. J. Exp. Bot. 2010, 61, 747-754. [CrossRef] [PubMed]

8. El-Garhy, H.A.S.; Khattab, S.; Moustafa, M.M.A.; Abou Ali, R.; Abdel Azeiz, A.Z.; Elhalwagi, A.; el Sherif, F. Silybin Content and Overexpression of Chalcone Synthase Genes in Silybum marianum L. Plants under Abiotic Elicitation. Plant Physiol. Biochem. 2016, 108, 191-202. [CrossRef] [PubMed]

9. El Sherif, F.; Khattab, S.; Ibrahim, A.K.; Ahmed, S.A. Improved Silymarin Content in Elicited Multiple Shoot Cultures of Silybum marianum L. Physiol. Mol. Biol. Plants 2013, 19, 127-136. [CrossRef]

10. Bulgari, R.; Franzoni, G.; Ferrante, A. Biostimulants Application in Horticultural Crops under Abiotic Stress Conditions. Agronomy 2019, 9, 306. [CrossRef]

11. Mangundayao, K.; Yasurin, P. Bioactivity of Moringa oleifera and Its Applications: A Review. J. Pure Appl. Microbiol. 2017, 11, 43-50. [CrossRef]

12. Zulfiqar, F.; Casadesús, A.; Brockman, H.; Munné-Bosch, S. An Overview of Plant-Based Natural Biostimulants for Sustainable Horticulture with a Particular Focus on Moringa Leaf Extracts. Plant Sci. 2020, 295, 110194. [CrossRef]

13. Alkuwayti, M.A.A.; El-Sherif, F.; Yap, Y.-K.; Khattab, S. Foliar Application of Moringa oleifera Leaves Extract Altered StressResponsive Gene Expression and Enhanced Bioactive Compounds Composition in Ocimum basilicum. S. Afr. J. Bot. 2020, 129, 291-298. [CrossRef]

14. ElSherif, F.; Albotnoor, N.; Yap, Y.K.; Meligy, A.; Khattab, S. Enhanced Bioactive Compounds Composition in Lavandula officinalis In vitro Plantlets Using $\mathrm{NaCl}$ and Moringa oleifera, Aloe vera and Spirulina platensis Extracts. Ind. Crop. Prod. 2020, 157, 112890. [CrossRef]

15. Batool, S.; Khan, S.; Basra, S.M.A. Foliar Application of Moringa Leaf Extract Improves the Growth of Moringa Seedlings in Winter. S. Afr. J. Bot. 2020, 129, 347-353. [CrossRef]

16. Hoque, T.S.; Rana, M.S.; Zahan, S.A.; Jahan, I.; Abedin, M.A. Moringa Leaf Extract as a Bio-Stimulant on Growth, Yield and Nutritional Improvement in Cabbage. Asian J. Med Biol. Res. 2020, 6, 196-203. [CrossRef]

17. Ngcobo, B.L.; Bertling, I. Influence of Foliar Moringa oleifera Leaf Extract (MLE) Application on Growth, Fruit Yield and Nutritional Quality of Cherry Tomato. Acta Hortic. 2021, 1306, 249-254. [CrossRef]

18. Kanchani, A.M.K.D.M.; Harris, K.D. Effect of Foliar Application of Moringa (Moringa oleifera) Leaf Extract with Recommended Fertilizer on Growth and Yield of Okra (Abelmoschus esculentus). Agriest 2019, 13, 38-54. [CrossRef]

19. Dao, T.T.H.; Linthorst, H.J.M.; Verpoorte, R. Chalcone Synthase and Its Functions in Plant Resistance. Phytochem. Rev. 2011, 10, 397-412. [CrossRef] [PubMed]

20. Sepideh, S.; Shobbar, S.Z.; Ebrahimi, M.; Hasanloo, T.; Sadat-Noori, S.-A.; Tirnaz, S. Chalcone Synthase Genes from Milk Thistle (Silybum marianum): Isolation and Expression Analysis. J. Genet. 2015, 94, 611-617. [CrossRef]

21. Makkar, H.P.S.; Becker, K. Nutrional Value and Antinutritional Components of Whole and Ethanol Extracted Moringa oleifera Leaves. Anim. Feed. Sci. Technol. 1996, 63, 211-228. [CrossRef]

22. Horwitz, W.; Chichilo, P.; Reynolds, H. Official Methods of Analysis of the Association of Official Analytical Chemists; Association of Official Analytical Chemists: Washington, DC, USA, 1970.

23. Piper, C.S. Soil and Plant Analysis; Hans Publishers: Cambridge, MA, USA, 1942.

24. Mazumdar, B.C.; Majumder, K. Methods of Physiochemical Analysis of Fruits; Daya Publisher: Delhi, India, 2003.

25. Livak, K.J.; Schmittgen, T.D. Analysis of Relative Gene Expression Data Using Real-Time Quantitative PCR and the 2- $\Delta \Delta C T$ Method. Methods 2001, 25, 402-408. [CrossRef]

26. StatSoft STATISTICA for Windows, Version 6; 2300; StatSoft Inc.: Tulsa, OK, USA, 2001.

27. Ali, E.F.; Hassan, F.A.S.; Elgimabi, M. Improving the Growth, Yield and Volatile Oil Content of Pelargonium graveolens L. Herit by Foliar Application with Moringa Leaf Extract through Motivating Physiological and Biochemical Parameters. S. Afr. J. Bot. 2018, 119, 383-389. [CrossRef]

28. Van Zelm, E.; Zhang, Y.; Testerink, C. Salt Tolerance Mechanisms of Plants. Annu. Rev. Plant Biol. 2020, 71, 403-433. [CrossRef] 
29. Zhao, S.; Zhang, Q.; Liu, M.; Zhou, H.; Ma, C.; Wang, P. Regulation of Plant Responses to Salt Stress. Int. J. Mol. Sci. $2021,22,4609$. [CrossRef]

30. Zhu, J.K. Salt and Drought Stress Signal Transduction in Plants. Annu. Rev. Plant Biol. 2002, 53, 247-273. [CrossRef] [PubMed]

31. Aslam, M.; Sultana, B.; Anwar, F.; Munir, H. Foliar Spray of Selected Plant Growth Regulators Affected the Biochemical and Antioxidant Attributes of Spinach in a Field Experiment. Turk. J. Agric. For. 2016, 40, 136-145. [CrossRef]

32. Park, H.J.; Kim, W.Y.; Yun, D.J. A New Insight of Salt Stress Signaling in Plant. Mol. Cells 2016, 39, 447-459. [CrossRef] [PubMed]

33. Elsayed, A.I.; El-Hamahmy, M.A.M.M.; Rafudeen, M.S.; Mohamed, A.H.; Omar, A.A. The Impact of Drought Stress on Antioxidant Responses and Accumulation of Flavonolignans in Milk Thistle (Silybum marianum (L.) Gaertn). Plants 2019, 8, 611. [CrossRef] [PubMed]

34. Rady, M.M.; Mohamed, G.F. Modulation of Salt Stress Effects on the Growth, Physio-Chemical Attributes and Yields of Phaseolus vulgaris L. Plants by the Combined Application of Salicylic Acid and Moringa oleifera Leaf Extract. Sci. Hortic. 2015, 193, 105-113. [CrossRef]

35. Yasmeen, A.; Basra, S.M.A.; Farooq, M.; ur Rehman, H.; Hussain, N.; ur Rehman Athar, H. Exogenous Application of Moringa Leaf Extract Modulates the Antioxidant Enzyme System to Improve Wheat Performance under Saline Conditions. Plant Growth Regul. 2013, 69, 225-233. [CrossRef]

36. Latif, H.H.; Mohamed, H.I. Exogenous Applications of Moringa Leaf Extract Effect on Retrotransposon, Ultrastructural and Biochemical Contents of Common Bean Plants under Environmental Stresses. S. Afr. J. Bot. 2016, 106, 221-231. [CrossRef]

37. Howladar, S.M. A Novel Moringa oleifera Leaf Extract Can Mitigate the Stress Effects of Salinity and Cadmium in Bean (Phaseolus vulgaris L.) Plants. Ecotoxicol. Environ. Saf. 2014, 100, 69-75. [CrossRef] [PubMed]

38. De Vasconcelos, A.C.F.; Garófalo Chaves, L.H. Biostimulants and Their Role in Improving Plant Growth under Abiotic Stresses. In Biostimulants in Plant Science; IntechOpen: London, UK, 2020.

39. Khalofah, A.; Bokhari, N.A.; Migdadi, H.M.; Alwahibi, M.S. Antioxidant Responses and the Role of Moringa oleifera Leaf Extract for Mitigation of Cadmium Stressed Lepidium sativum L. S. Afr. J. Bot. 2020, 129, 341-346. [CrossRef]

40. Abbas, S.; Zaglool, M.; El-Ghadban, E.; Abd El-Kareem, S.; Waly, A. Effect of Moringa Leaf Extract Spray on Sage (Salvia officinalis L.) Plant under Sandy Soil Conditions. Hortsci. J. Suez Canal Univ. 2016, 5, 15-21. [CrossRef]

41. Drouet, S.; Tungmunnithum, D.; Lainé, É.; Hano, C. Gene Expression Analysis and Metabolite Profiling of Silymarin Biosynthesis during Milk Thistle (Silybum marianum (L.) Gaertn.) Fruit Ripening. Int. J. Mol. Sci. 2020, 21, 4730. [CrossRef]

42. Elwekeel, A.; Elfishawy, A.; Abouzid, S. Silymarin Content in Silybum marianum Fruits at Different Maturity Stages. J. Med. Plant Res. 2013, 7, 1665-1669. [CrossRef]

43. Torres, M.; Corchete, P. Gene Expression and Flavonolignan Production in Fruits and Cell Cultures of Silybum marianum. J. Plant Physiol. 2016, 192, 111-117. [CrossRef] [PubMed] 